\title{
Desain Sistem Aplikasi Les Privat Menggunakan Pendekatan Extreme Programming
}

\author{
Mansur $^{1}$, Risma Yani $^{2}$, Kasmawi $^{3}$ \\ ${ }^{1,2}$ Program Studi DIII-Teknik Informatika Politeknik Negeri Bengkalis \\ ${ }^{3}$ Program Studi DIV-Rekayasa Perangkat Lunak Politeknik Negeri Bengkalis \\ (Jalan Bathin Alam, Sungai Alam, Bengkalis, Riau , telp. (+62766) 800 1000) \\ email: mansur@polbeng.ac.id ${ }^{1}$, rismayani0628@ gmail.com ${ }^{2}$, kasmawi@polbeng.ac.id ${ }^{3}$
}

\begin{abstract}
Abstrak
Indonesia saat ini telah mewajibkan pendidikan selama 12 tahun dengan kurikulum 2013, dimana kedua orang tua dituntut keterlibatannya dalam memperhatikan pendidikan anaknya. Salah satu tindakannya yaitu mendaftarkan anaknya ke tempat-tempat bimbingan belajar seperti les privat. Di kota Bengkalis proses untuk mendapatkan informasi tentang keberadaan guru les diproleh dari rekan kerja, tetangga dan sosail media. Namun, informasi yang disampaikan juga tidak lengkap sehingga para orang tua sulit menemukan calon guru sesuai dengan kebutuhan. Pada dasarnya les privat menjadi suatu kebutuhan bagi setiap orang namun hal tersebut masih bersifat mahal, sehingga beberapa orang tua mencari informasi guru relawan yang membuka kelas belajar tambahan yang sifatnya gratis. Tujuan penelitian ini yaitu melakukan desain sistem aplikasi les privat menggunakan pendekatan extreme programming. Aplikasi dibangun dengan menggunakan bahasa pemrograman PHP dengan framework codeigniter dan MySql sebagai database. Penelitian ini menghasilkan sebuah desain aplikasi yang dapat membantu orang tua murid dengan mudah memperoleh informasi terkait les privat baik berbayar maupun gratis, orang tua juga dapat memonitoring jam belajar anak melalui absensi. Keunggulan aplikasi ini yaitu dapat membuka lapangan pekerjaan bagi calon guru les yang memiliki keahlian dibidang ilmu tertentu dengan mengoptimalkan ketersediaan waktu guru.
\end{abstract}

Kata Kunci - Desain Sistem, Les Privat, Framework Codeigniter, Extreme Programming

\begin{abstract}
Abstrack - Indonesia currently requires 12 years of education with the 2013 curriculum, where both parents are required to be involved in paying attention to their children's education. One of his actions is enrolling his child in tutoring places such as privattutoring. In the city of Bengkalis, the process of getting information about the whereabouts of tutors was obtained from coworkers, neighbors and social media. However, the information conveyed is also incomplete, so parents find it difficult to find prospective teachers according to their needs. Basically, privattutoring is a necessity for everyone, but it is still expensive, so some parents look for information on volunteer teachers who open additional free learning classes. The purpose of this study is to design a privattutoring application system using the extreme programming approach. The application is built using the PHP programming language with a Codeigniter framework and MySql as a database. This research resulted in an application design that can help students' parents easily obtain information related to privattutoring both paid and free, parents can also monitor children's learning hours through attendance. The advantage of this application is that it can open up employment opportunities for prospective tutors who have expertise in certain fields of science by optimizing the availability of teacher time.
\end{abstract}

Keywords - Design System, Private Lessons, Framework Codeigniter, Extreme Programming

eISSN: 2477-3255, pISSN: 2086-4884 https://doi.org/10.31849/digitalzone.v11i1.3862 


\section{Pendahuluan}

Les privat merupakan suatu proses kegiatan belajar-mengajar yang dilakukan diluar jam sekolah. Dalam artian bahasa Inggris private berarti (pribadi, sendiri). Berdasarkan definisi tersebut, Les Privat adalah proses belajar-mengajar yang dibimbing oleh seorang tutor, maupun guru yang memiliki keahlian pada bidang ilmu tertentu untuk melatih siswa secara pribadi diluar jam belajar sekolah, yang biasanya dengan jumlah siswa lebih sedikit dibandingkan dengan jumlah siswa yang berada disekolahan pada umumnya, banyak peyedia jasa les privat sudah melakukan hal tersebut dengan memanfaatkan teknologi berbasis web untuk mempertemukan calon guru les dengan orang tua atau murid dalam mendapatkan informasi sesuai dengan kriteria yang diinginkan[1]. Les atau bimbingan belajar dapat membantu orang tua dalam memberikan pendidikan tambahan kepada anak untuk memaksimalkan pendidikan yang didapat disekolah[2]. Banyak teknologi yang digunakan dalam menyampaikan informasi terkait les baik melalui marketplace maupun media online[3], media tersebut didukung oleh perkembangan teknologi informasi dalam melakukan promosi tempat les privat kepada pengguna sehingga informasi yang disajikan tepat sasaran[4].

Beberapa penelitian menyatakan bahwa tujuan dalam melakukan desain aplikasi adalah untuk memenuhi kebutuhan pemakai sistem dan memberikan gambaran yang jelas serta rancangan yang lengkap kepada pembuat sistem sehingga apa yang diinginkan dapat terlaksana dengan baik [5]. Dalam mendesain sebuah sistem aplikasi les privat perlu memperhatikan proses penjadwalan terhadap kegiatan belajar mengajar untuk mempermudah dalam mengelola data jadwal guru dan menjadi pedoman bagi orang tua atau siswa dalam memilih hari sesuai dengan kebutuhannya. Dalam mendesain sistem dengan baik memerlukan metode SDLC (System Development Life Cycle) sehingga hasil yang dinginkan sesuai kebutuhan pengguna[6]. Selain metode SDLC, metode XP (Extreme Programming) juga dapat membuat sebuah aplikasi dengan cepat dan mudah, serta dapat diterapkan pada berbagai permasalahan seperti membuat aplikasi perhitungan kuota sks mengajar dosen berbasis web baik static maupun dinamis [7],[8]. XP juga mampu menyelesaikan permasalahan pada seleksi peserta pelatihan kerja berbasis web dengan baik sesuai dengan kebutuhan pengguna[9].

Bengkalis merupakan salah satu kota pendidikan yang diwacanakan oleh pemerintah Kabupaten Bengkalis yang dituangkan melalui visi, misi dan program kerja pemerintah. Keinginan tersebut tidaklah mudah terutama dalam membetuk sumber daya manusia yang handal dalam menghadapi berbagai masalah, untuk itu perlu suatu upaya dalam membantu pemerintah dalam mewujudkan cita-cita melalui pengembangan sumber daya manusia melalui palayanan jasa guru les privat. Pelayanan jasa les privat belum terpusat dan masih dikerjakan oleh setiap guru atau konvensional, mulai dari orang tua murid yang harus mengunjungi lembaga-lembaga bimbingan belajar satu-persatu, forward melalui sosial media, hingga meminta rekomendasi dari teman, saudara dan kerabat yang sudah pernah menggunakan jasa les privat tersebut sebelumnya. Selain itu, untuk melakukan pemesanan guru les privat juga masih dilakukan secara konvensional dan tentu tidak memberikan hasil yang maksimal, karena membutuhkan proses yang cukup panjang dalam menemukan calon guru les privat yang benarbenar sesuai dengan kebutuhan.

Pada penyesuaian jadwal kegiatan les juga terdapat permasalahan yang kompleks dan sering dihadapi, antara calon guru dengan murid, kemudian keluhan dari para orang tua murid terkait kompetensi, prestasi dan track-record dari calon guru les yang menjadi patokan sebagai guru les privat terbaik. Pentingnya penjadwalan bagi setiap orang adalah sebagai rencana kegiatan kedalam bentuk daftar catatan yang berisi kegiatan sehari-hari[10]. Disisi lain ditemukan juga sebagian orang tua yang belum mampu untuk mendaftarkan anaknya ke bimbingan belajar atau les privat disebabkan oleh faktor biaya. Pada dasarnya saat ini les privat menjadi suatu kebutuhan bagi setiap orang namun masih bernilai mahal, sehingga orang tua 
juga mencari informasi mengenai belajar tambahan yang bersifat gratis. Oleh sebab masih banyak masyarakat atau kelompok/individu yang menyediakan tempat pembelajaran secara gratis seperti kelas mengaji, kelas relawan pemuda membaca, dan lainya.

Berdasarkan permasalahan tersebut, diperlukan suatu desain sistem aplikasi les privat berbasis web yang dapat membantu mempermudahkan masyarakat dalam mencari informasi tentang jasa pembukaan kelas les baik yang berbayar maupun gratis yang dilakukan oleh para guru relawan. Selain itu, sistem tersebut dapat memberikan peluang usaha kepada guru les dan masyarakat yang memiliki potensi mengajar untuk berbagi pengalaman kepada masyarakat melalui pembuakaan kelas. Desain sistem ini dirancang menggunakan pendekatan extreme programming $(X P)$ yang dapat menghasilkan informasi kepada masyarakat seperti informasi guru les berbayar dan gratis, menampilkan jadwal ketersediaan guru, menampilkan data matapelajaran bidang studi, matapelajaran khusus seperti bahasa inggris, mandarin, dan bahasa arab, serta dapat melakukan pemesanan jasa les kepada guru yang bersangkutan.

\section{Metode Penelitian}

Penelitian ini menggunakan pendekatan extreme programming $(X P)$ dalam mendesain sistem aplikasi les privat yang terdiri dari 4 (empat) tahapan yaitu[2][7][11]:

1) Planning

Pada tahap planning perlu dilakukan kegiatan identifikasi permasalahan terkait les privat, mengetahui dan melakukan analisa alur sistem yang existing dan new system untuk kebutuhan dan penetapan pelaksanaan pembuatan sistem.

2) Design

Pada tahap design ini perlu dilakukan perancangan sistem untuk aplikasi les privat menggunakan diagram Unified Modelling Language (UML) untuk menampilkan pemodelan sistem, dan pemodelan arsitektur. Sedangkan untuk perancangan database menggunakan Entity Relationship Diagram (ERD).

3) Coding

Pada tahap coding merupakan langkah dalam pembuatan sistem les privat dengan memperhatikan tahapan desain yang sudah dilakukan. Bahasa yang digunakan dalam membuat aplikasi yaitu PHP dengan framework codeigniter, sementara database menggunakan MySQL.

4) Testing

Tahap ini merupakan langkah terakhir untuk mengetahui apakah desain sistem aplikasi les privat dapat digunakan sesuai dengan kebutuhan pengguna. Pengujian dilakukan dengan menggunakan metode blackbox testing.

Gambar 1 menunjukan tahapan yang dilakukan dalam menggunakan pendekatan extreme programming.

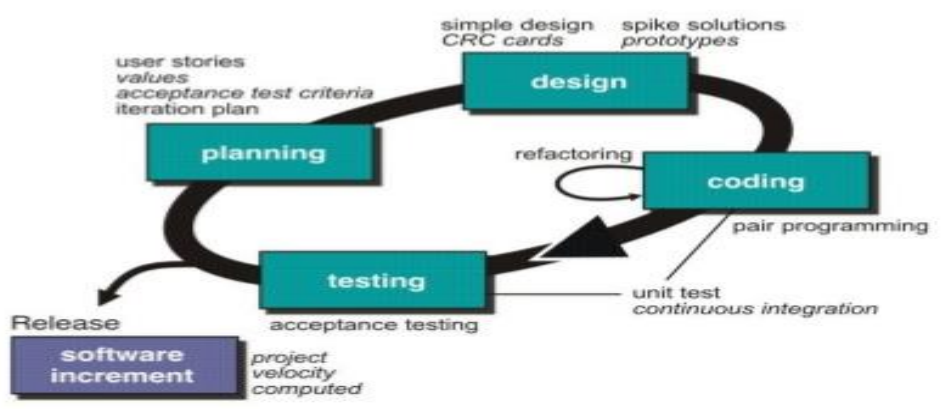

Gambar 1. Tahapan Proses extreme programming[12] 


\section{Hasil dan Pembahasan}

Hasil penelitian ini berupa sebuah sistem aplikasi les privat berbasis web dengan menggunakan pendekatan extreme programming $(X P)$ yang dapat mempermudah masyarakat dalam mendapatkan informasi seperti informasi guru les berbayar dan guru relawan (gartis), menampilkan jadwal ketersediaan guru, kelola absensi, menampilkan data matapelajaran bidang studi, matapelajaran khusus seperti bahasa inggris, mandarin, dan bahasa arab, serta dapat melakukan pemesanan jasa les kepada guru yang bersangkutan. Selain itu, aplikasi tersebut memberikan peluang usaha kepada guru les dan masyarakat yang memiliki potensi mengajar untuk berbagi pengalaman kepada masyarakat melalui pembuakaan kelas. Berikut pembahasana mengenai tahapan extreme programming sebagai berikut:

1) Tahap Planning

Menjelaskan tentang alur sistem baru (new system) dari desain sistem aplikasi les privat. Alur tersebut melibatkan beberapa user yaitu:

a. User admin; dapat mengelola sistem aplikasi les privat secara keseluruhan baik proses input, update, delete, melihat data, melakukan validasi user guru, dan user orang tua murid sebagai front usernya.

b. User guru; dapat melakukan login, register, edit data, CRUD riwayat pendidikan, membuat kelas paket, guru kelas, membuat kelas gratis, dan dapat menerima pesanan dari user orang tua murid.

c. User orang tua murid; dapat melakukan registrasi, login, melihat informasi guru secara detail, mencari guru berdasarkan mata pelajaran dan jenjang, melakukan proses pemesanan berdasarkan paket yang tersedia, melihat jadwal ketersediaan guru mengajar, melakukan transfer, mengisi absensi, melihat informasi guru relawan untuk mecari les privat gratis.

Untuk lebih jelas tentang alur desain sistem aplikasi les private dapat dilihat pada gambar 2.

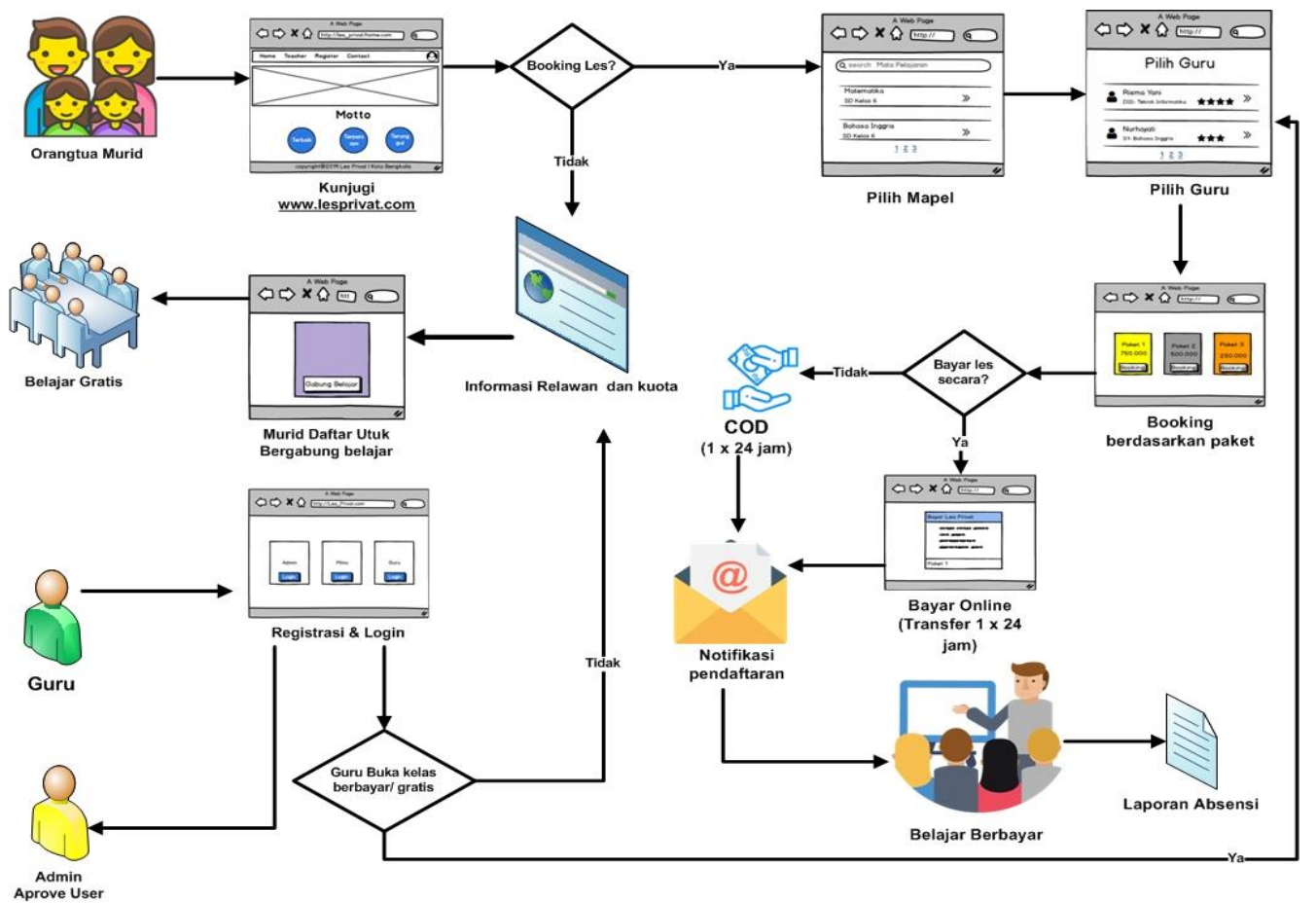

Gambar 2. Alur Sistem Aplikasi Les Privat 
2) Tahap Design

Dalam melakukan desain sistem menggunakan Unified Modelling Language (UML) system untuk membuat Usecase Diagram, dan Activity Diagram, sedangkan untuk database menggunakan ERD dan LRS (Logical Relationship Structure).

a. UseCase Diagram

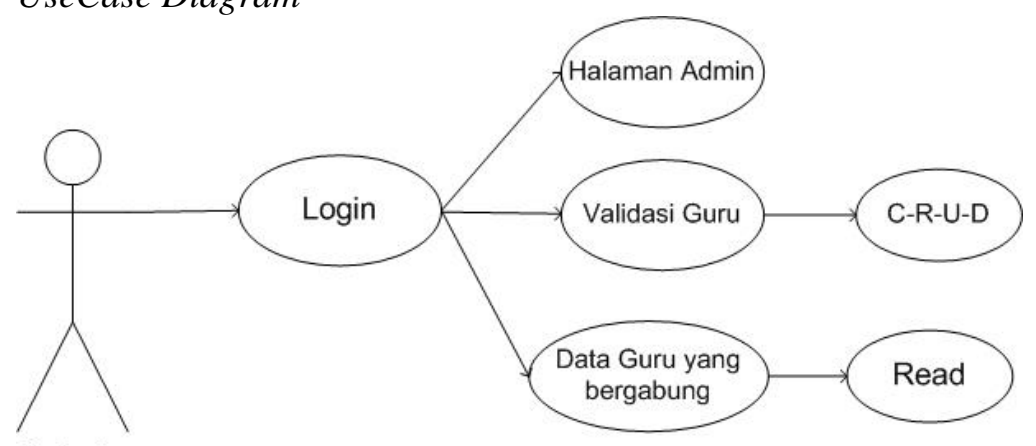

Admin

Gambar 3. Usecase diagram untuk admin

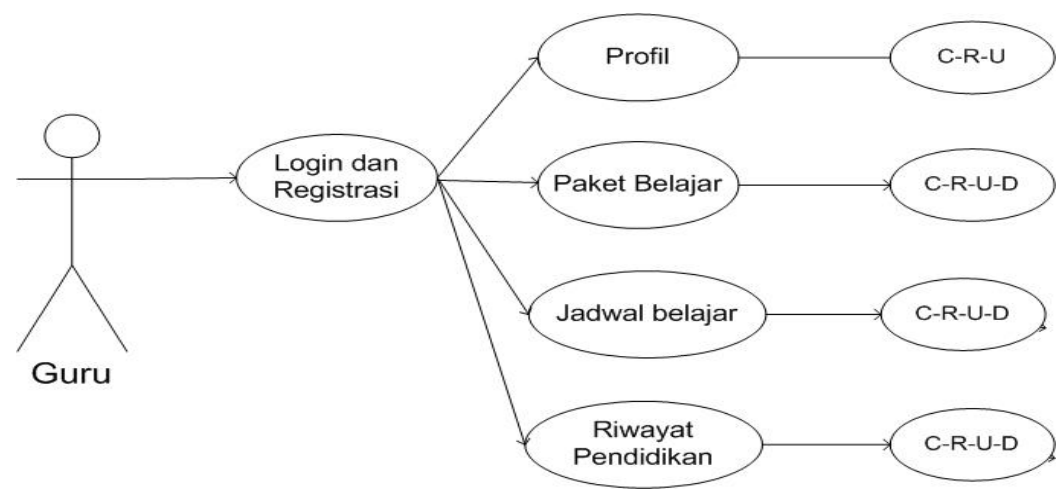

Gambar 4. Usecase Diagram untuk guru

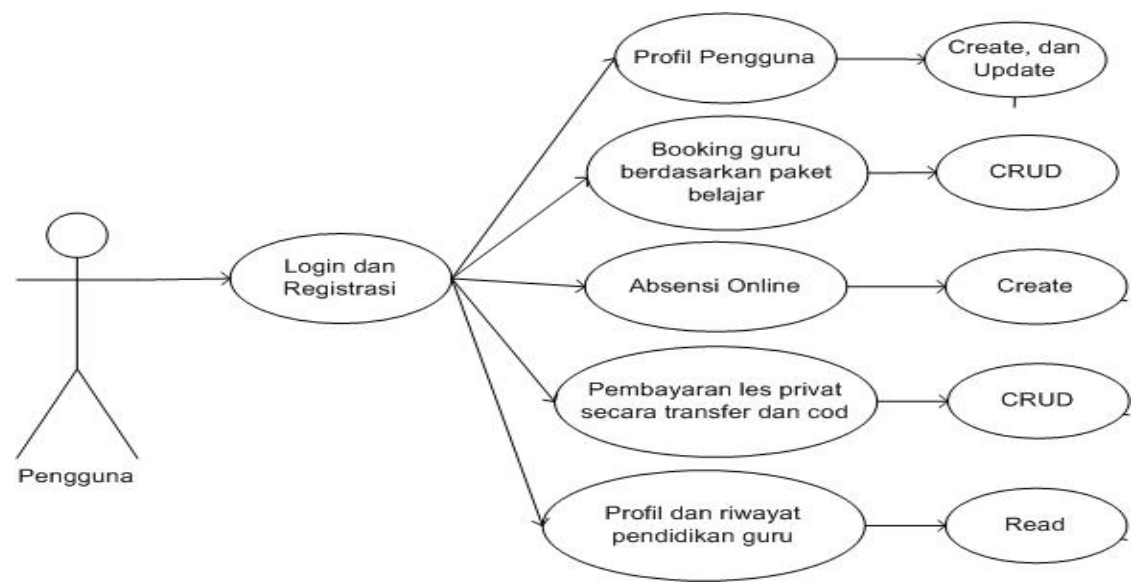

Gambar 5. Usecase Diagram untuk pengguna 
b. Activity diagram untuk melakukan input data.

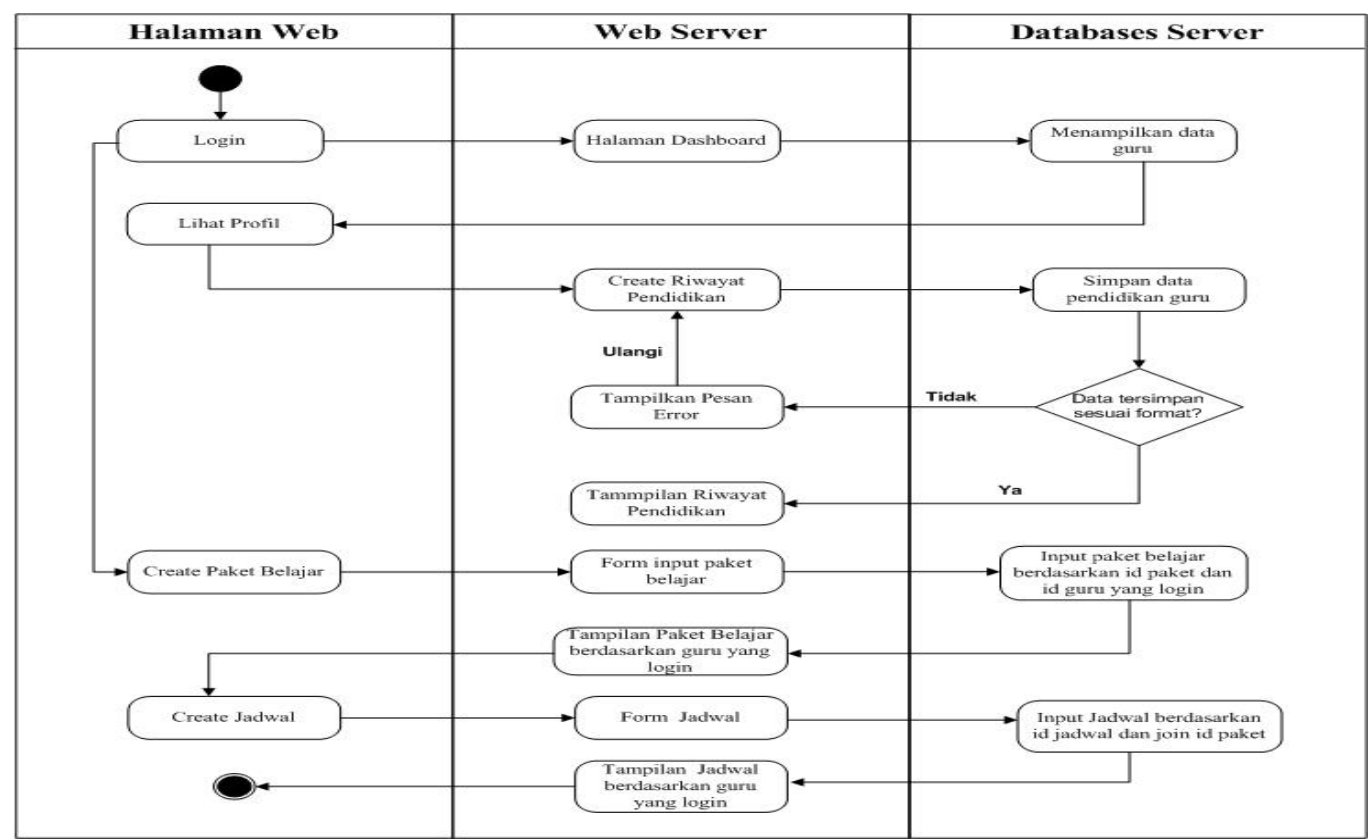

Gambar 6. Activity diagram input data untuk user guru

\section{c. Entity Relationship Diagram}

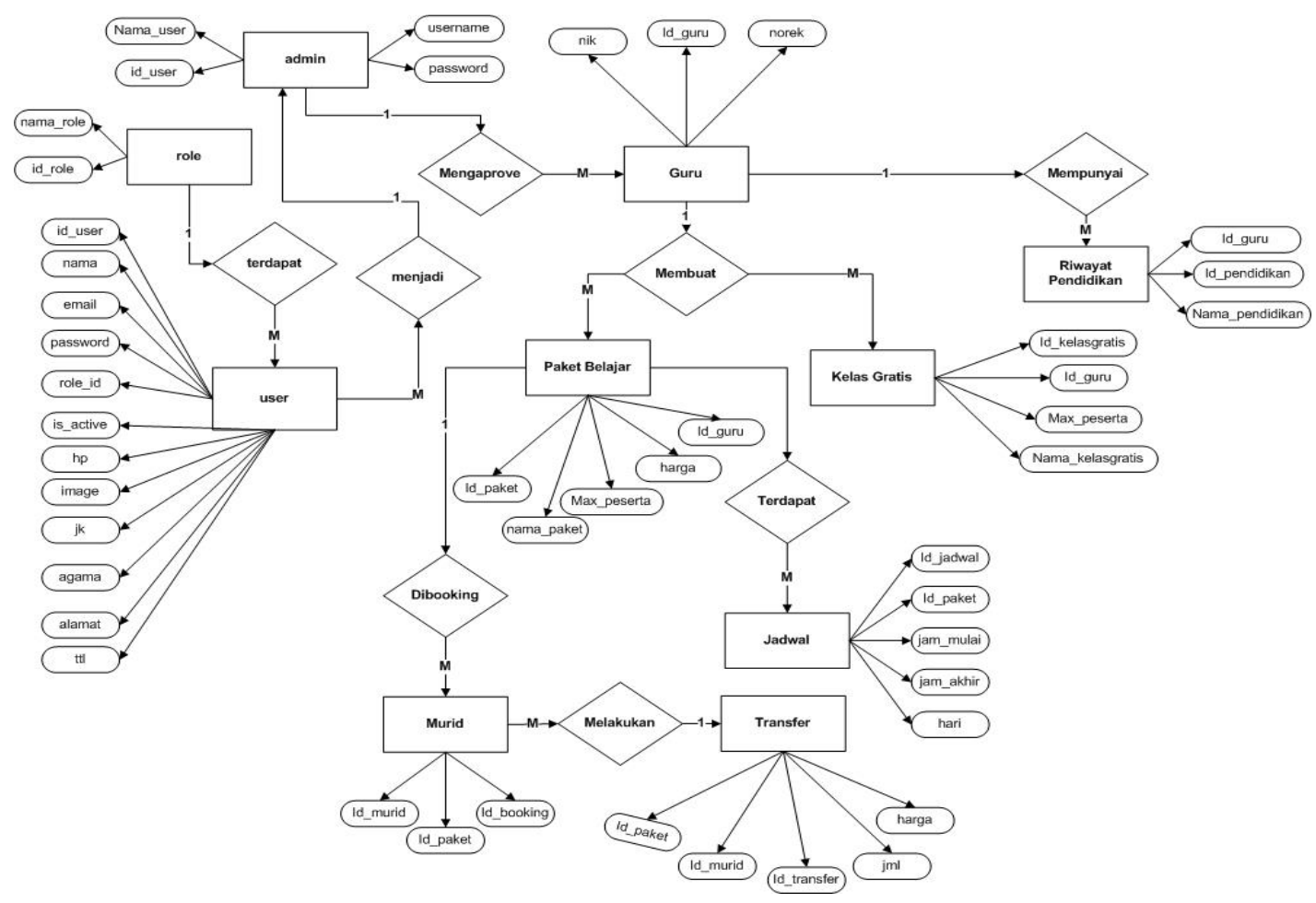

Gambar 7. Entity relationship diagram (ERD) 


\section{d. Logical Relationship Structure}

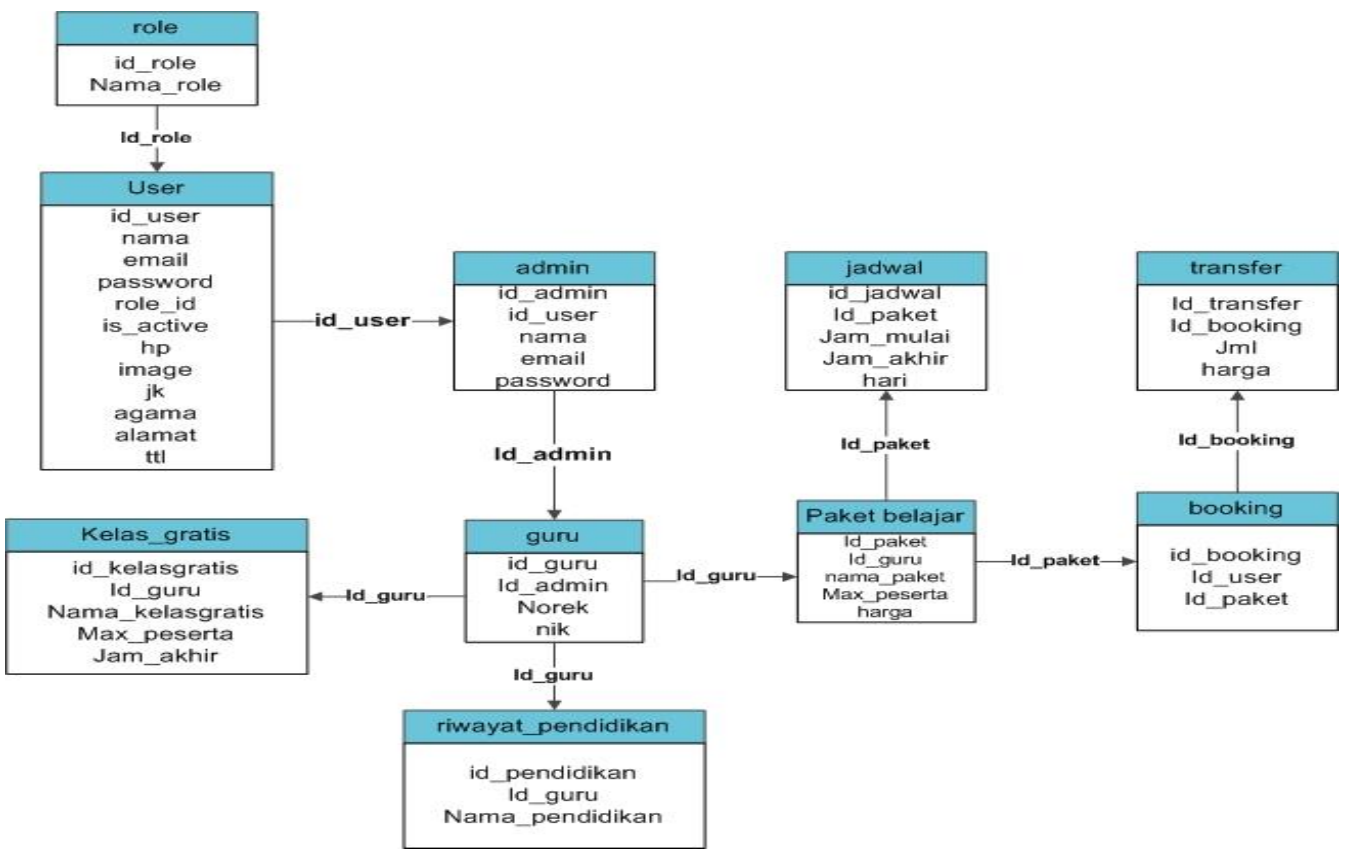

\section{1) Coding}

Gambar 8. Logical relationship structure

Pada tahapan ini, proses pembuatan aplikasi sudah mulai dilakukan dengan cara menyusun source code sesuai dengan perancangan sistem yang diusulkan.

Gambar 9 merupakan form input dan source code untuk registrasi guru dan orang tua murid.

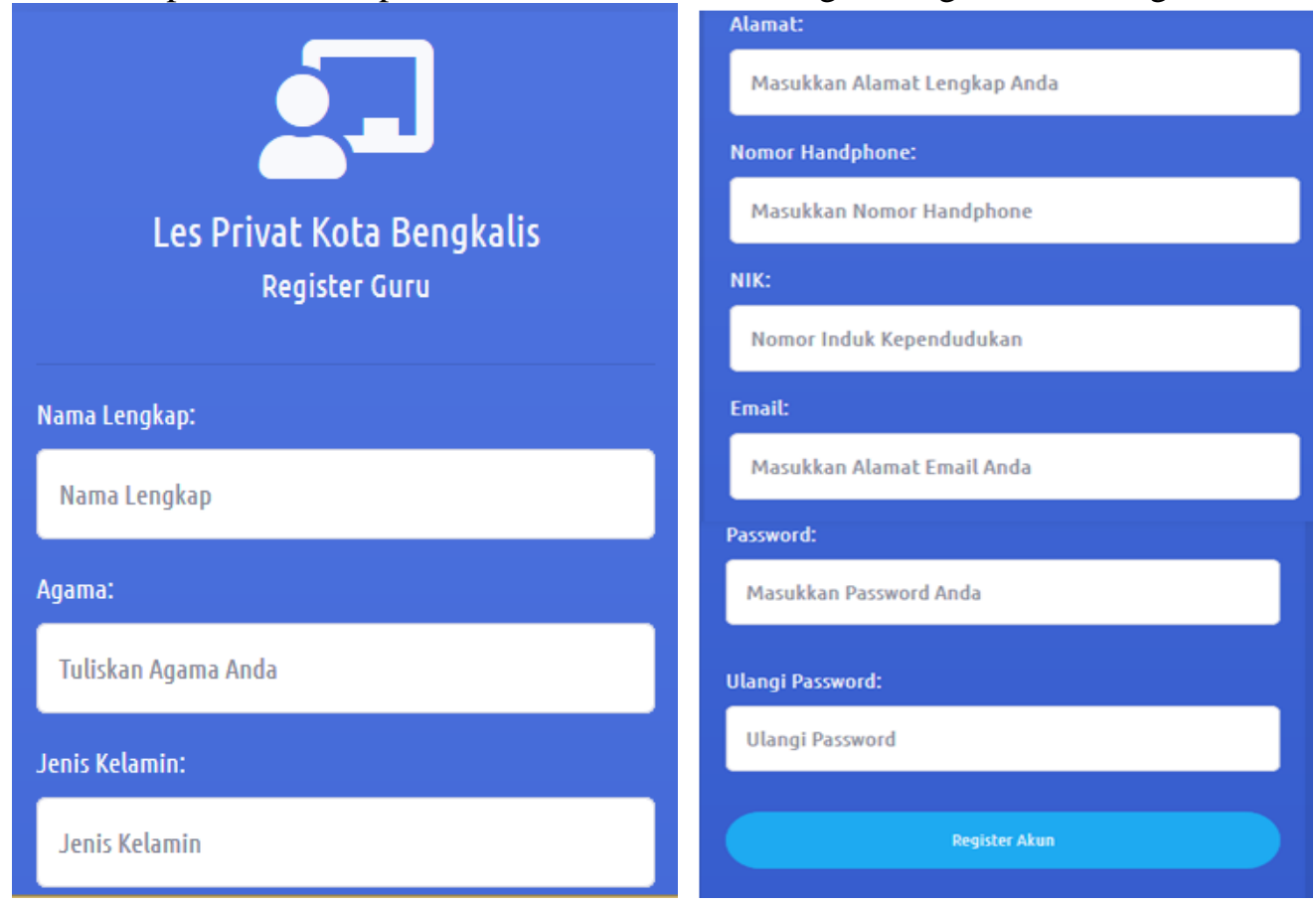

Gambar 9. form input dan source code registrasi guru dan orang tua murid. 


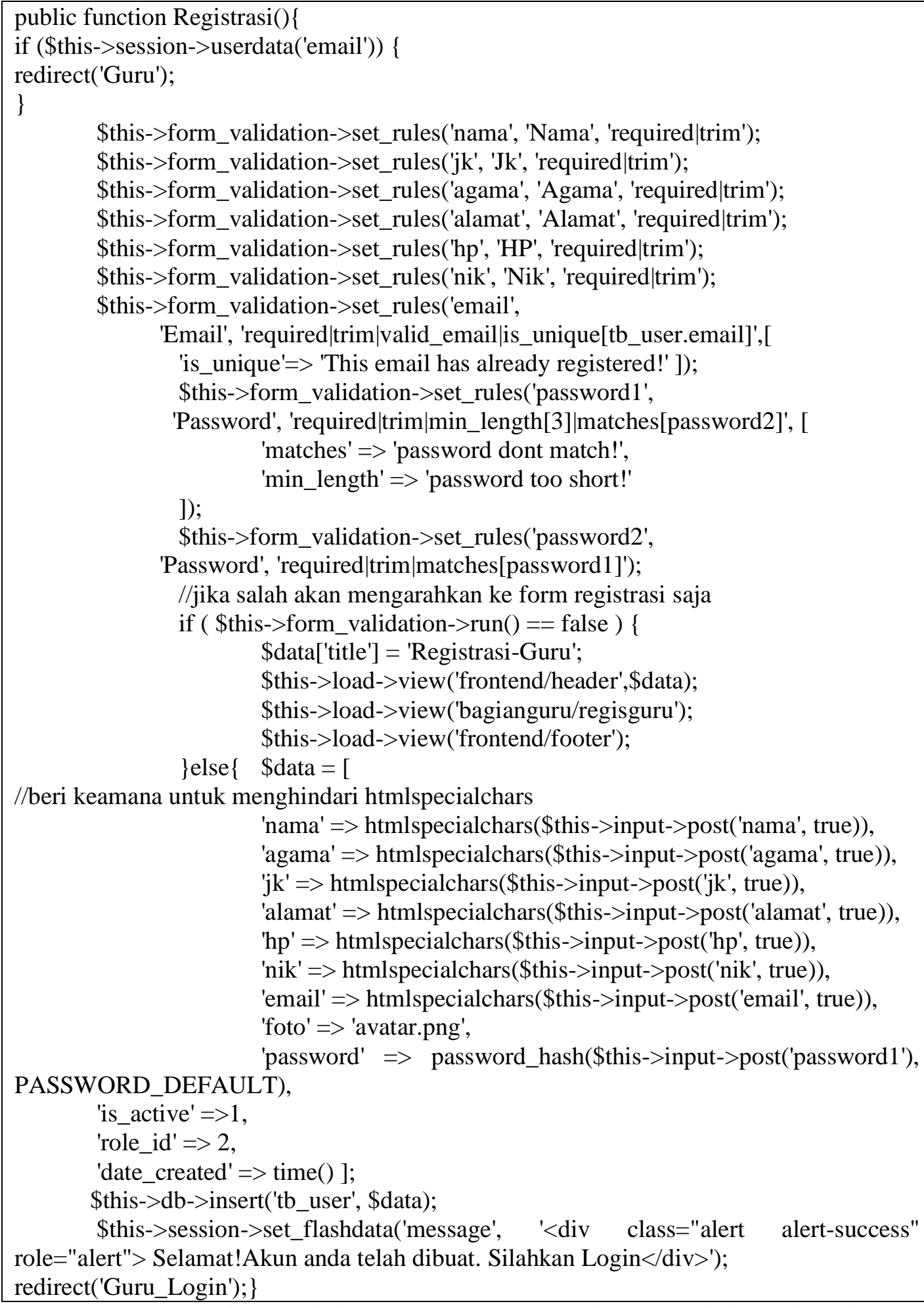

Gambar 10 merupakan form penjadwalan, source code untuk guru dan informasi bagi orang tua murid. 


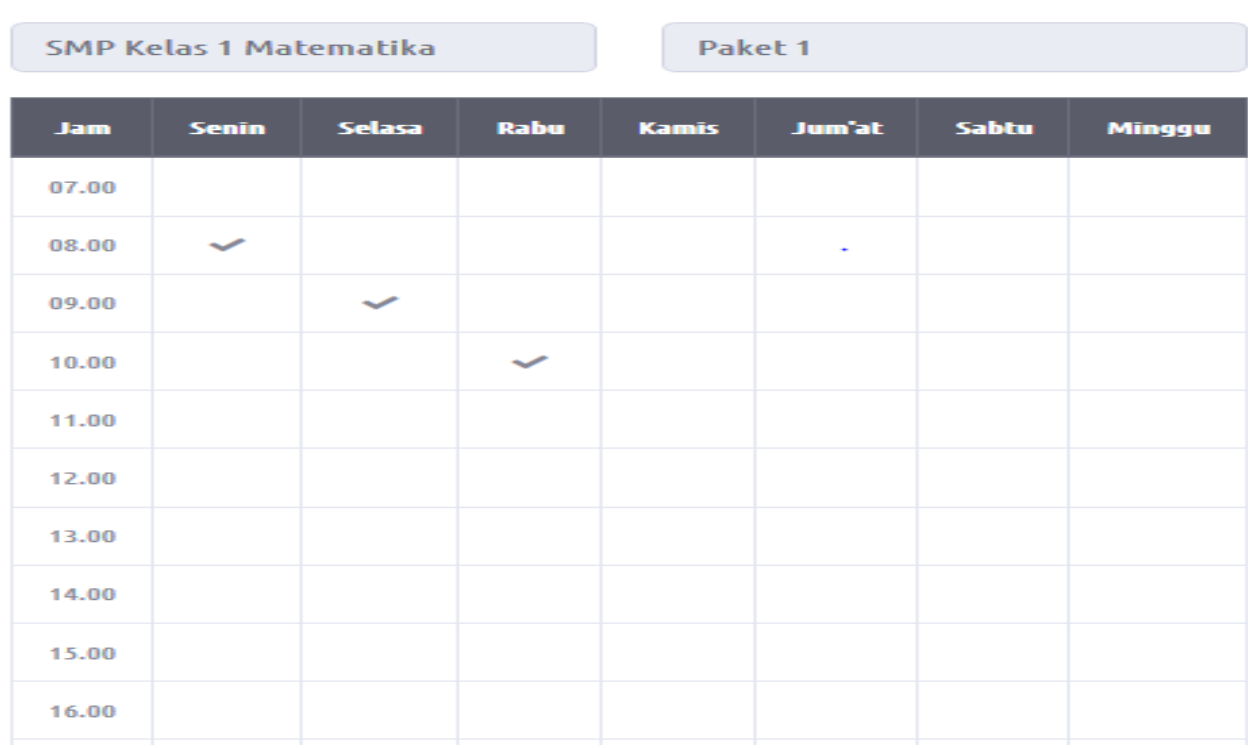

Gambar 10. Form Input Jadwal dan source code untuk guru serta orang tua murid

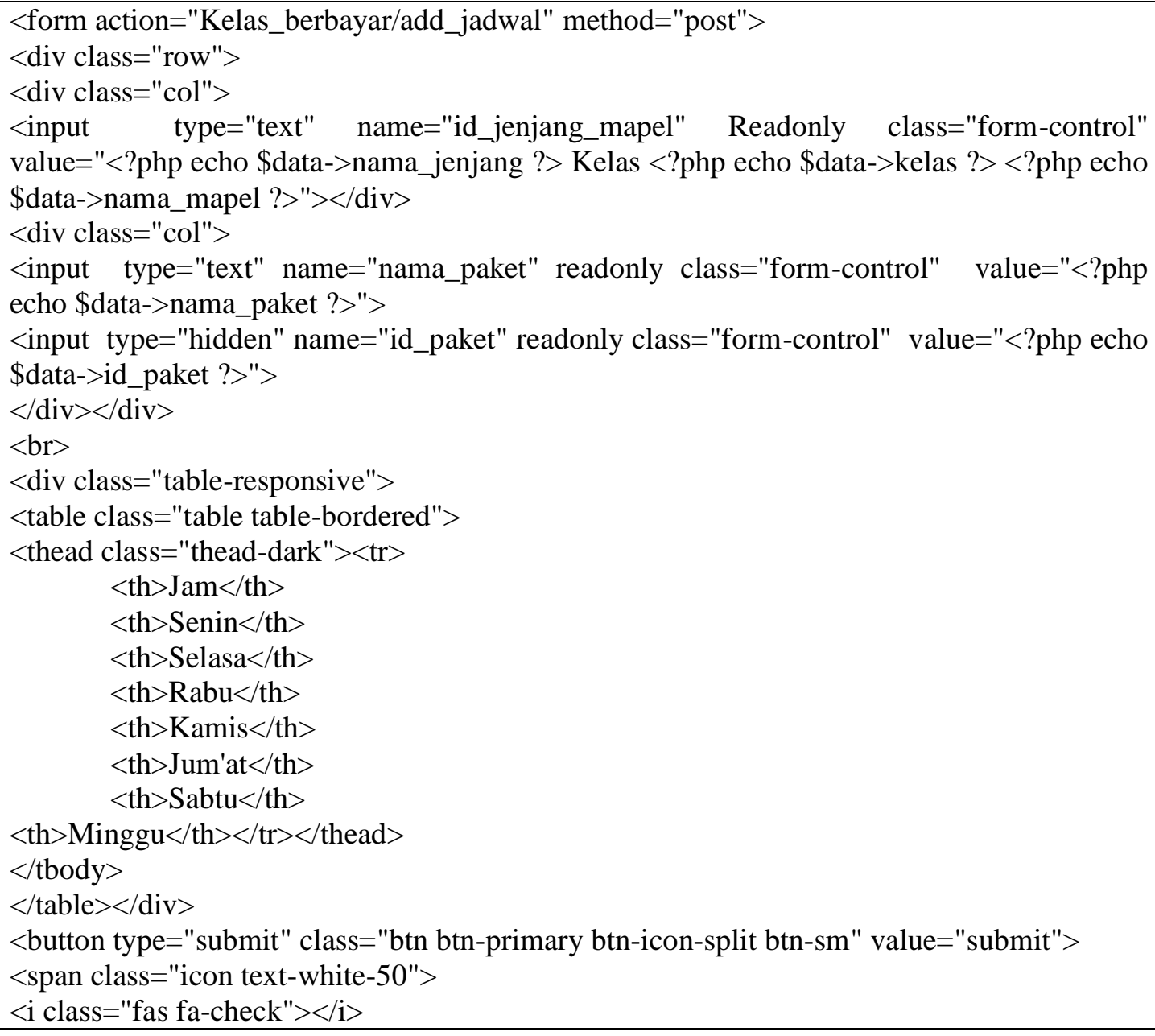




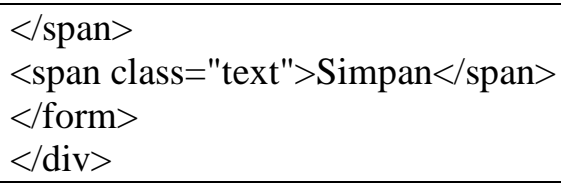

Gambar 11 merupakan form pesanan dan source code orang tua murid dalam melakukan pesanan kepada guru untuk matapelajaran/guru kelas.

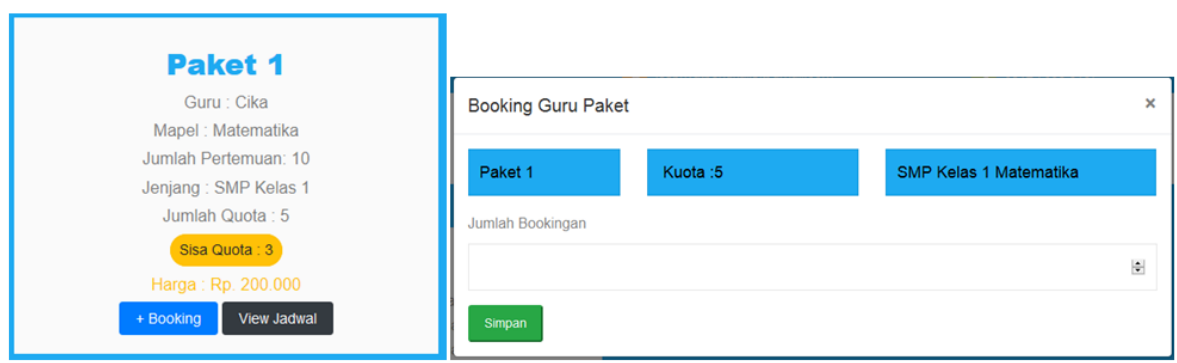

Gambar 11. Form pesanan dan source code orang tua murid melakukan pesanan.

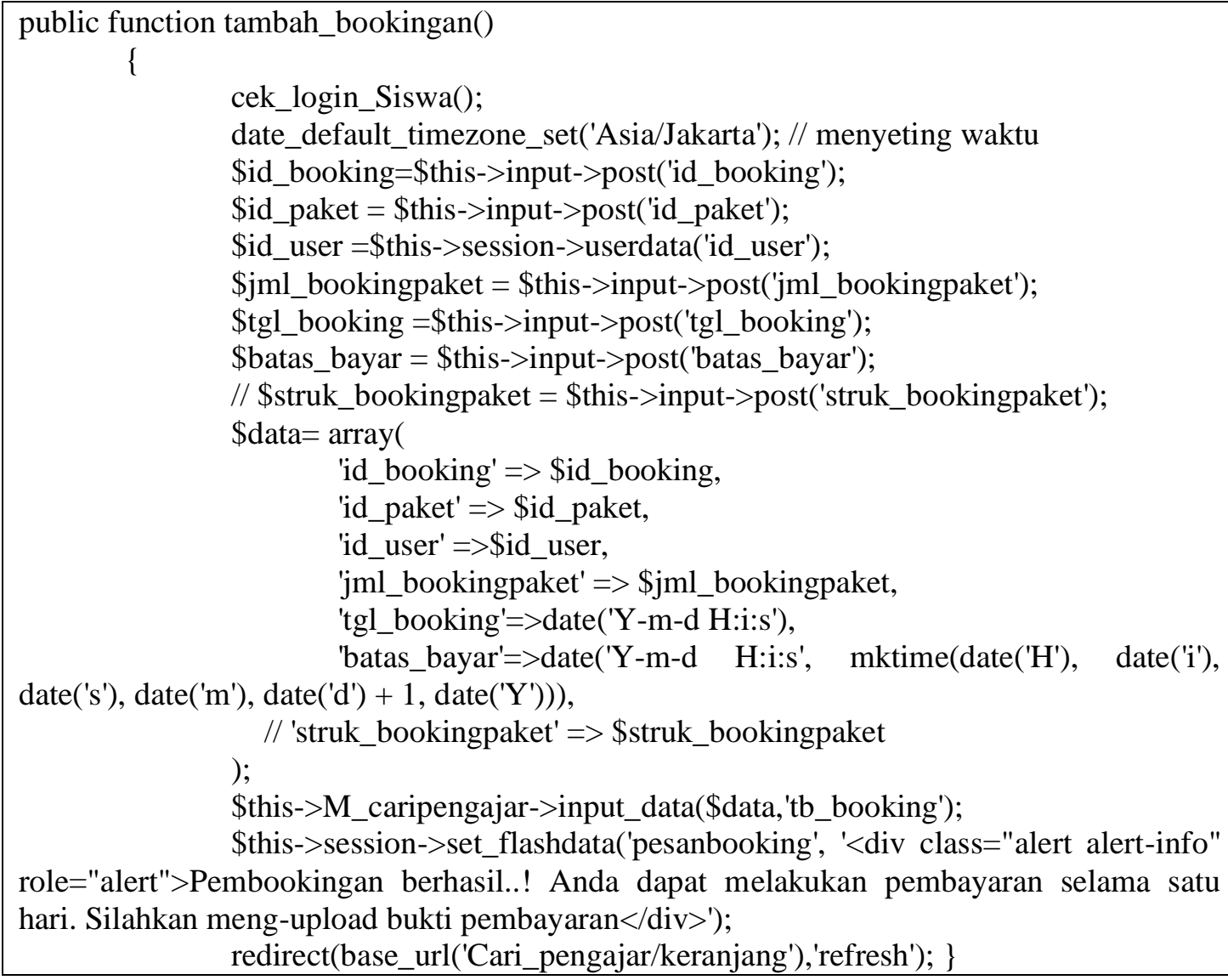

3) Tahapan Testing

Untuk mengetahui tingkat keberhasilan pada design sistem aplikasi les privat yang menggunakan pendekatan XP, maka perlu dilakukan pengujian hasil desain tersebut sebagai berikut: 
Tabel I. Pengujian Form Login User (admin, guru dan orang tua murid)

\begin{tabular}{|c|c|c|c|c|}
\hline $\begin{array}{c}\text { Skema } \\
\text { Pengujian }\end{array}$ & Teste Case & $\begin{array}{l}\text { Hasil Yang } \\
\text { diharapkan }\end{array}$ & Hasil Pengujian & Kesimpulan \\
\hline $\begin{array}{l}\text { Pengujian } \\
\text { pada form } \\
\text { Registrasi. }\end{array}$ & $\begin{array}{l}\text { Guru dan } \\
\text { pengguna } \\
\text { menginputkan } \\
\text { biodata } \\
\text { pribadi. }\end{array}$ & $\begin{array}{l}\text { Menyimpan } \\
\text { biodata kedalam } \\
\text { tabel user. }\end{array}$ & $\begin{array}{l}\text { Aplikasi akan } \\
\text { Menangkap } \\
\text { email dan } \\
\text { password untuk } \\
\text { proses } \\
\text { selanjutnya } \\
\text { (sesuai harapan). }\end{array}$ & $\begin{array}{l}\text { Data tersimpan ke } \\
\text { dalam tabel user } \\
\text { dimana hak akses } \\
\text { diberikan } \\
\text { berdasarkan role } \\
\text { id. role_id } 1= \\
\text { admin, } 2=\text { guru } \\
\text { dan 3= pengguna. }\end{array}$ \\
\hline $\begin{array}{l}\text { Pengujian } \\
\text { pada form } \\
\text { login }\end{array}$ & $\begin{array}{l}\text { Admin, guru } \\
\text { dan user dapat } \\
\text { melakukan } \\
\text { login setelah } \\
\text { data terdaftar } \\
\text { di tabel user. }\end{array}$ & $\begin{array}{l}\text { Aplikasi dapat } \\
\text { membaca serta } \\
\text { mencocokkan } \\
\text { username dan } \\
\text { password yang } \\
\text { sudah terdaftar } \\
\text { sebelumnya. }\end{array}$ & $\begin{array}{lr}\text { Login } & \text { dapat } \\
\text { berhasil jika } \\
\text { email dan } \\
\text { password yang } \\
\text { dimasukkan } \\
\text { adalah benar jika } \\
\text { tidak maka } \\
\text { aplikasi akan } \\
\text { menampilkan } \\
\text { pesan error. } \\
\text { (sesuai harapan) }\end{array}$ & $\begin{array}{l}\text { Admin, guru dan } \\
\text { pengguna dapat } \\
\text { login serta } \\
\text { mengakses } \\
\text { beberapa } \\
\text { kebutuhan yang } \\
\text { sudah di tentukan } \\
\text { sebelumnya. }\end{array}$ \\
\hline $\begin{array}{l}\text { Pengujian } \\
\text { update } \\
\text { profile. }\end{array}$ & $\begin{array}{l}\text { Guru dan } \\
\text { pengguna } \\
\text { melakukan } \\
\text { update profile } \\
\text { guna } \\
\text { melengkapi } \\
\text { biodata yang } \\
\text { belum lengkap. }\end{array}$ & $\begin{array}{l}\text { Dapat melakukan } \\
\text { update profile } \\
\text { dengan data yang } \\
\text { benar. }\end{array}$ & $\begin{array}{lr}\text { Profiler yang } \\
\text { sudah di } & \text { update } \\
\text { akan secara } \\
\text { otomatis } \\
\text { merubah data } \\
\text { profile yang } \\
\text { sebelumnya } \\
\text { (sesuai harapan) }\end{array}$ & $\begin{array}{lr}\text { Guru dan } \\
\text { pengguna dapa } \\
\text { melakukan update } \\
\text { profile sesuai } \\
\text { dengan kebutuhan } \\
\text { mereka. }\end{array}$ \\
\hline $\begin{array}{l}\text { Pengujian } \\
\text { form guru } \\
\text { paket dan } \\
\text { guru kelas }\end{array}$ & $\begin{array}{l}\text { Guru dapat } \\
\text { melakukan } \\
\text { CRUD pada } \\
\text { form guru } \\
\text { paket dan guru } \\
\text { kelas. }\end{array}$ & $\begin{array}{lr}\text { Guru } & \text { yang } \\
\text { membuat } & \text { kelas } \\
\text { dapat } & \\
\text { menyesuaikan } \\
\text { dengan bidang } \\
\text { ilmurrar serta } \\
\text { kemampuan yang } \\
\text { dimiliki. }\end{array}$ & $\begin{array}{l}\text { Pengujian sangat } \\
\text { responsive } \\
\text { ketika dilakukan } \\
\text { pada layar yang } \\
\text { berukuran } \\
\text { medium dan } \\
\text { large (sesuai } \\
\text { harapan) }\end{array}$ & $\begin{array}{l}\text { Data yang diolah } \\
\text { oleh guru tersebut } \\
\text { akan menjadi } \\
\text { sebuah informasi } \\
\text { di sisi pengguna, } \\
\text { terkait harga, } \\
\text { quota, jenjang dan } \\
\text { mata pelajaran } \\
\text { yang di dibuat } \\
\text { tersebut. }\end{array}$ \\
\hline
\end{tabular}

Putra, dkk [1] membahas tentang aplikasi marketplace sebagai penyedia jasa les privat menggunakan metode waterfall untuk melakukan proses pencarian, menyeleksi, dan menemukan guru les dengan filter berdasarkan matapelajaran, jenis kelamin, harga, rating, lokasi terdekat, menampilkan data profil guru seperti pilihan jenjang mengajar, jadwal, tentang guru, portofolio, review, menyediakan fasilitas permintaan mengajar kepada guru yang diinginkan, pembayaran les berdasarkan pertemuan, serta berfungsi sebagai media promosi berbasis web untuk menyampaikan informasi secara luas kepada masyarakat. Berdasarkan hasil 
survey dari 25 responden dapat disimpulkan bahwa hasil yang diperoleh sangat positif dan dapat diterima oleh masyarakat[1]. Namun, pada penelitian ini membahas tentang pencarian guru berdasarkan paket, jenjang pendidikan, jenis kelamin, track record guru, absensi siswa sebagai fasilitas memonitoring jam belajar anak, mengelola kelas guru relawan (gratis), menampilkan mata pelajaran guru kelas, bidang keahlian, pembayaran les berdasarkan paket dengan kriteria COD dan transfer, dapat menentukan batas waktu transfer maksimal, dan hasilnya dapat diterapkan pada browser dilaptop dan smartphone secara responsive.

\section{Kesimpulan}

Berdasarkan hasil penelitian tentang desain sistem aplikasi les privat menggunakan pendekatan extreme programming $(X P)$, maka dapat ditarik kesimpulan bahwa sistem aplikasi les privat dapat melayani masyarakat dalam mencari informasi terkait dengan guru les paket berdasarkan mata pelajaran, guru les berdasarkan bidang seperti bahasa inggris, mandarin, arab, menampilkan riwayat pendidikan guru, melihat jadwal ketersediaan guru, pembayaran les berdasarkan paket dengan kriteria COD dan transfer, menentukan batas waktu transfer maksimal, dan menyediakan fasiltas kelas berbayar dan kelas ralawan (gratis) bagi masyarakat yang kurang mampu dalam hal biaya. Sedangkan kemudahan bagi guru atau seorang relawan yaitu pengaturan jadwal untuk membuka kelas pada jam-jam tertentu, media promosi, dan pengelolaan kelas berbasis web. Selain itu, Setiap pengguna aplikasi yang bergabung pada aplikasi les privat dituntut secara moral untuk dapat memahami perkembangan teknologi sehingga kesadaran masyarakat akan kegunaan serta manfaat teknologi informasi menjadi terbiasa.

\section{Daftar Pustaka}

[1] A. K. Putra, D. R. Nyoto, and H. S. Pratiwi, "Rancang Bangun Aplikasi Marketplace Penyedia Jasa Les Private Di Kota Pontianak Berbasis Web," J. Sist. dan Teknol. Inf., vol. 5, no. 1, pp. 22-25, 2017.

[2] T. Afrizal, H. Sulaiman, and N. Isnain, "Bimbingan Belajar Bunglon Group," Semin. Nas. Dan Disk. Panel Multidisiplin Has. Penelit. Pengabdi. Kpd. Masy., pp. 113-118, 2018.

[3] F. Ayu and W. Sholeha, "Rancang bangun sistem informasi penjadwalan mata pelajaran berbasis web pada smart center pekanbaru," Intra-Tech, vol. 3, no. 1, pp. 38-48, 2019.

[4] Wulandari and I. Rofni, "Implementasi teknologi tepat guna kepada masyarakat," Semin. Has. Pengabdi. Masy., vol. ISSN : 261, no. November, pp. 175-180, 2018.

[5] Mansur, Kasmawi, and S.Nurdin, "System design for business location searching using distance approach based on Android System design for business location searching using distance approach based on Android," Conf. Ser. 1450 012066, vol. 1, pp. 1-9, 2020.

[6] R. Hermawan, A. Hidayat, and V. G. Utomo, "Sistem Informasi Penjadwalan Kegiatan Belajar Mengajar Berbasis Web (Studi Kasus : Yayasan Ganesha Operation Semarang) Rudi," J. Evolusi Vol. 4 Nomor 1, vol. 4 Nomor 1, no. lppm3.bsi.ac.id/jurnal, pp. 72-79, 2016.

[7] A. H. M. H. Ali, S. Raviraja, and O. I. Eldai, "increment iterative extreme programming ( iixp ) methodology for developing static web presence Faculty of Computer Science, University of Medical Sciences and Technology, Khartoum, Sudan Faculty of Computer Science, University of Sudan of Sciences an," pp. 1-5, 2008.

[8] C. Irmawati and A. Supriyatna, "Penerapan Metode Extreme Programming Dalam Perancangan Aplikasi Perhitungan Kuota Sks Mengajar Dosen," Univ. Bina Sarana Inform. Jakarta, Vol. 3, No. 1, Pp. 106-113, 2019. 
[9] A. Supriyatna, "Metode Extreme Programming Pada Pembangunan Web Aplikasi Seleksi Peserta Pelatihan Kerja," Tek. Inform., Vol. 11, No. 1, Pp. 1-18, 2018.

[10] Rahmah and Mansur, "Desain dan implementasi sistem penjadwalan agenda berbasis android," J. Teknol. Inf. Komun. Digit. Zo., vol. 8, no. 2, pp. 196-206, 2017.

[11] R. Fojtik, "Procedia Computer," Procedia Comput. Sci., vol. 3, pp. 1464-1468, 2011.

[12] I. Carolina and A. Rusman, "Penerapan Extreme Programming Pada Sistem Informasi Penjualan Pakaian Berbasis Web ( Studi Kasus Toko ST Jaya )," J. Inovtet Polbeng-Seri Inform., vol. 4 No 2, no. teknologi, pp. 157-167, 2019.

\section{(c) $\underset{\mathrm{BY}}{\mathrm{i}}$ ()} Creative Commons Attribution International (CC BY-SA 4.0) 